\title{
The Economic Value of Kimhy Reserve in Backan, Vietnam
}

\author{
Ho Ngoc Cuong*, Nguyen Van Song\#, Vu Ngoc Huyen \\ Faculty of Economics and Rural Development (FERD), Vietnam National University of Agriculture (VNUA), Trauquy, Gialam, \\ Hanoi, Vietnam \\ Email: "nguyensonghua@gmail.com
}

How to cite this paper: Cuong, H. N., Song, N. V., \& Huyen, V. N. (2020). The Economic Value of Kimhy Reserve in Backan, Vietnam. Modern Economy, 11, 522-532. https://doi.org/10.4236/me.2020.112038

Received: January 16, 2020

Accepted: February 22, 2020

Published: February 25, 2020

Copyright (c) 2020 by author(s) and Scientific Research Publishing Inc. This work is licensed under the Creative Commons Attribution International License (CC BY 4.0).

http://creativecommons.org/licenses/by/4.0/

\begin{abstract}
This study conducted to examine the total economic value (TEV) of Kimhy Reserve by using a combination of Stated Preference approach and Market-based approach such as market price method, replacement cost, avoidable cost. The results indicated that Kimhy Reserve has use value and non-use value. The TEV of Kimhy Reserve for adjacent community was about 3.3 billion VND per year, equivalent to USD 364.83 per household. The economic value generated from direct use value accounted for about $67 \%$. The result also pointed out that the indirect use value was about $23 \%$. It was clear seen that almost livelihood of the adjacent community was relative to Kimky Reserve. Given the high level of illegal natural resource extraction and wildlife trade, the livelihood of community around is affected seriously. The results of study recommend that the economic and environmental value of Kimhy Reserve should be recognized by local community. The policies should be implemented better to protect Kimhy Reserve.
\end{abstract}

\section{Keywords}

Kimhy Reserve, Economic Value, Backan, Vietnam

\section{Introduction}

Kimhy Reserve is located in the north of Backan province, Vietnam, covering a total of 15,000 ha in the two districts: Nari and Bachthong. This area is abundant with natural resources such as: plant, animals and minerals. There are 798 species of plant, in which 65 species are very rare that have been recorded in the UCN Red List of Threatened Species. The fauna of Kimhy reservation is 386 species, in which 56 species are recorded in the UCN Red List of Threatened Species (Nari People's Committee, 2013, 2014, 2015). Almost of mineral in *First author, ${ }^{*}$ Corresponding author. 
Kimhy is gold that has the high value. Kimhy Reserve plays an important role in diversity protection, climate equable and community's livelihood such as: timber, medicine plants. In recent years, although the economic benefit generated for local people from Kimhy Reserve, the illegal natural resource extraction, and wildlife trade Kimhy Reserve have been uncontrollable. Song (2008) pointed out that high profitability of illegal wildlife trade is the main reason for the rapid growth in the illegal trade and highlights key failure in the country's attempts to control it. It has direct as well as indirect significantly adverse impact on ecosystem in Kimhy Reserve and in Vietnam. There are many rare species disappear without trace. The livelihood of community around is affected seriously. One of the best solutions to protect better Kimhy Reserve than before is that the economic value of Kimhy Reserve is needed to assess. It will enhance the sense of agents concerned to protect Kimhy Reserve. However, the ecosystem services of Kimhy Reserve such as clean air and water, and natural calamity, and some provisioning services related to local community are not traded in markets or undervalued. In particular, this study will be the first to estimate the economic value of Kimhy Reserve.

Estimating the economics and environmental value derived from Kimhy Reserve will contribute to the scant body of knowledge on the economic value of Forest Reserves. Such knowledge on the economic benefits of Forest Reserves will provide a better understanding on the roles that Forest Reserves on our society. Moreover, the result of this study will provide significant contributions on the management and improvement of Kimhy Reserve, as well as in the preservation and enhancement of the environment quality of the area. There are two approaches have been developed to place an economic value on non-market goods and services: reveal preference (RP) and stated preference (SP) methods (Atkinson and Mourato, 2008). Therefore, a combination of Stated Preference approach and Market-based approach were used to assess the economic values including market and non-market goods and services of Kimhy Reserve. The study aims to answer the following questions: 1) How is the situation of Kimhy Reserve? 2) What is the economic and environmental value of Kimhy Reserve?

\section{Literature Review of Economic Value of Reserves}

Reserves are areas that are protected in order to keep safe the animals and plants that live there. Like many ecosystems, reserves have use and non-use value. The common way to estimate the value of use market value is using market prices or shadow prices in case of the appearance of distortion in this market (Truong, 2012). However, in term of other use values and non-use values such as climate regulation, bequest value, existence value, stated preference approach is more commonly used to estimate those values. In literature, there are studies conducted to estimate economic value of reserves.

Riccardo et al. (1999) used data from a large-scale contingent valuation study are used to investigate the effects of forest attributes on willingness to pay for 
forest recreation in Ireland. The yearly impact on visitors' economic welfare of new nature reserves approaches half a million pounds per annum, exclusive of non-recreational values.

Xue and Tisdell (2000) stated that the most important of a forest ecosystem type of a nature reserve's values are its ecological functions which provide human beings and other living things with beneficial environmental services. These services include water conservancy, soil protection, $\mathrm{CO}_{2}$ fixation and $\mathrm{O}_{2}$ release, nutrient cycling, pollutant decomposition, and disease and pest control. They use opportunity cost and alternative cost methods to provide a monetary valuation of these services. Changbaishan Mountain Biosphere Reserve in Northeast China is valued at 510.11 million yuan (US 61.68\$ mill.) per year, 10 times higher than the opportunity cost (51.78 mill. yuan/ha) for regular timber production.

Rolfe and Windle (2005) in their study pointed out that option values may be an important component of non-use values when development options for environmental assets are considered. These are values that the community might hold for maintaining options to make future choices about allocating resources. They applied stated preference approach, namely choice modeling to assess the option values and non-use value of Fitzroy River Basin in central Queensland.

Ninan and Inoue (2013) conducted their study to know the benefits of forest reserve in Japan. This paper suggests that the annual value of the ecosystem services provided by forests is not only worth millions of dollars, but also in per hectare terms much more than hitherto known. This value for the Oku Aizu forest reserve ranged US $1.427 \$-1.482 \$$ billion or about US $17,016 \$-17,671 \$$ per ha.

Sharma et al. (2015) assessed the TEV of the selective ecosystem services of the Koshi Tappu Wildlife Reserve. They used the combination of market based and value transfer methods to estimate the economic benefit generated from the reserve was about US $16 \$$ million per year (equivalent to US 982\$/household).

\section{Research Methodology}

The study was conducted in Kimhy Reserve in 2016. Firstly, we had made a group discussion with local people, local leaders, officials and researchers to clarify the services of Kimhy Reserve. Then, questionnaire designed to get information to estimate the value of those services of Kimhy Reserve through face to face-interviewing.

\subsection{Data Collection}

The secondary data was obtained from research paper in journal, report of Nari committee and Kimhy Reserve board. The primary data was collected through interviewing with 80 samples, 60 in which is households and the others are officials, local leaders.

\subsection{Data Analyses}

The Kimhy Reserve has use value and non-use value, so we applied many ap- 
proaches and methods to measure the economic value of Kimhy Reserve such as market price, replacement cost, contingent valuation method, avoidable cost. We use those methods to study 60 samples and this result will be used to generalize for 400 household living near Kimhy Reserve.

The market-based method was applied to estimate the value of firewood, medicine plant, aquatic products from stream or honey. Those effects on the livelihood of households around Kimhy Reserve.

The values of Kimhy Reserve such as climate regulation, underground water management, soil stabilization, carbon sequestration, ... were measured by replacement cost.

The contingent valuation method was used to estimate the willingness to pay of households for protecting forest-Kimhy Reserve.

The other values of Kimhy Reserve including soil erosion, mitigating the natural calamity, floods, ... were estimated by avoidable cost.

\section{Results and Discussions}

\subsection{The Recognition of Economic Value of Kimhy Reserve in Kimhy Community}

Kimhy Reserve plays an important role for socio-economy in Kimhy community. The economic value recognition of Kimhy Reserve in Kimhy Community was known by group discussion with households, local leaders, officials and researchers. The economic value of Kimhy Reserve is shown in Figure 1.

\subsection{Estimation of the Economic Value of Kimhy Reserve in Kimhy Community}

\subsubsection{The Direct Value}

\section{Firewood}

The households in Kimhy community were used to look for firewood for cooking foods. Since 2003, although Kimhy Reserve was found to protect forest but the wood extraction has been going on because of the availability of wood, kind of cooker such as three-leg stove and financial situation. They usually take the firewood from the dead trees or broken branches. The value of firewood from forest in Kimhy community is shown in Table 1.

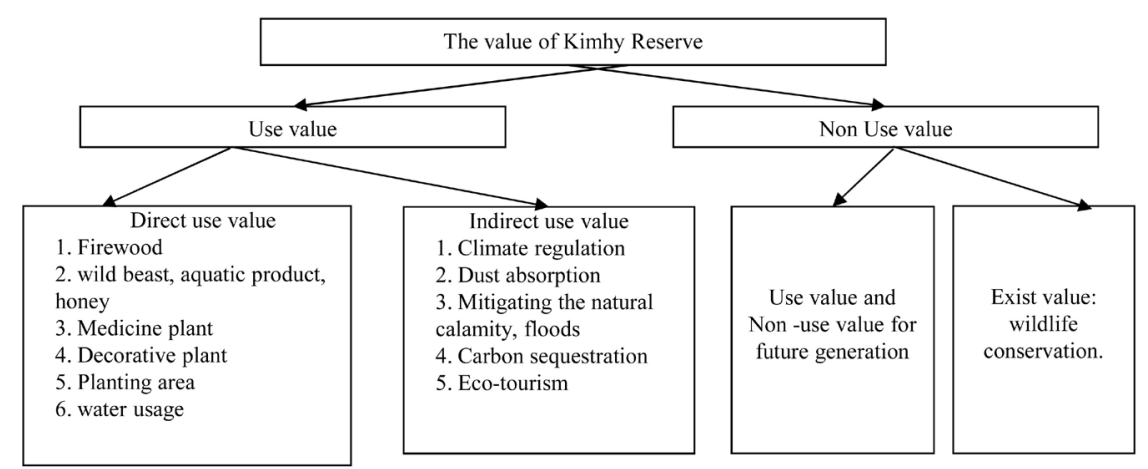

Figure 1. The economic value of Kimhy reserve. 
Table 1. The value of firewood from forest in Kimhy community, 60 household-respondents, Kimhy community, Na Ri, Backan, 2016. Unit: Thousand vietnam dong (1000 VND).

\begin{tabular}{ccc}
\hline No & Value of firewood from Kimhy Reserve & Value (1000 VND) \\
\hline 1 & Value of firewood/household/month & 272 \\
2 & Value of firewood/household/year & 3270 \\
3 & Total value of firewood in Kimhy Reserve, Kimhy commune/year & $1,264,000$ \\
\hline
\end{tabular}

Source: Survey results, 2016; 1 US $=23,000 \$$ VND.

Table 1 shows that the households around Kimhy Reserve in Kimhy commune usually collect firewood that is equivalent of 272/1000 VND per month per household or $3270 / 1000$ VND per year per household. Therefore, the total annual value of firewood from forest in Kimhy community is $1,264,000 / 1000$ VND.

\section{The value of wild beast, aquatic product, honey}

The wild beast in Kimhy Reserve is very abundant such stags, deers, ... as well as aquatic product and honey. The kind of species has been hunting including bamboo rat, civet, snake, chicken ... those can help community livelihood in Kimhy. The value of wild beast, aquatic product and honey is described in Table 2.

The number of households those hunted the the wild beast, aquatic product, honey is 7 (11.67\%) in total with the average amount of money 1200/1000 VND. It means the value of wild beast, aquatic product, honey in Kimhy/year is 56,000/1000 VND (see Table 2).

\section{The value of medicine plant}

There are many kind of medicine plant in Kimhy Reserve such as: Schefflera Octophylla (Lour.), Fallopia multiflora (Thunb.), Cibotium barometz J. Sm., Amomum xanthioides Wall. Morinda officinalis How, Plantago major L., ... However, only 16 medicine plants have been used mostly to treat common sick such as: stomachache, headache, fever, temperature, cough, arthritis, coxalgia, ... There is $96.67 \%$ households always going to the forest to take some medicine plant when they felt sick with the equivalent of 250/1000 VND/household/year. It means the total value of medicine plant in Kimhy Reserve in Kimhy commune is $96,670 / 1000 \mathrm{VND} /$ year.

\section{The value of decorative plant and water usage}

The local people in Kimhy Reserve found some plant can be traded as decorative plant including orchids and others. There is $60 \%$ households collecting some kind of decorative plants with the average annual value of 22,000/1000 VND. They also use water supported from stream or water fall in Kimhy for water usage every day (100\%). To estimate the value of provisioning water, we compare with the other place far from Kimhy, they usually spend 20/1000 VND per month on pumping or $240 / 1000 \mathrm{VND}$ per household per year. It means that the value of Kimhy in supporting water usage for household is $96,000 / 1000$ $\mathrm{VND} /$ year. 
Table 2. The value of wild beast, aquatic product, honey, 60 household-respondents, Kimhy community, Na Ri, Backan, 2016.

\begin{tabular}{cccc}
\hline No & Content & Unit & Value \\
\hline$I$ & Hunting the wild beast, aquatic product, honey & & \\
1 & Say "Yes" & Household & 7 \\
2 & Say "No" & Household & 53 \\
$I I$ & Species & & \\
1 & Birds & Household & 4 \\
2 & Honey & Household & 5 \\
3 & Others: Bamboo rats, Civets, Snakes, chicken & Household & 6 \\
$I I$ & The value of wild beast, aquatic product, honey & & \\
1 & The value of wild beast, aquatic product, honey/household/year & $1000 \mathrm{VND}$ & 1200 \\
2 & The value of wild beast, aquatic product, honey in Kimhy/year & $1000 \mathrm{VND}$ & 56,000 \\
\hline
\end{tabular}

Source: Survey results, 2016; 1US $=23,000 \$$ VND.

\section{The value of breeding and cultivation from Kimhy}

Breeding activities will not allow in Kimhy Reserve since 2003. However, some households (6.7\%) still keep breeding farm inside to feed buffalos, goats. They do not need spend any money on buying food for animals because forest grass is available. The value from breeding per household we calculated from the data we did the survey was $14,500 / 1000 \mathrm{VND} /$ household/year. Generally, the total annual value of breeding animal in Kimhy is $386,667 / 1000$ VND. Beside that the community also cultivated in some added area in Kimhy Reserve. There is $8.33 \%$ households having added terrace fields $\left(1000 \mathrm{~m}^{2} /\right.$ household $)$ with the value of products they got from that around 300/1000 $\mathrm{VND} /$ household/year or $10,000 / 1000 \mathrm{VND}$ in the total.

In Kimhy Reserve, there also have a lot of fruits and vegetables that people live around can harvest to consume or sell. There is $40 \%$ households harvest those kinds of fruits and vegetable with the equivalent of 2000/1000 VND/household/ year. This total value of Kimhy in supporting fruits and vegetables is 320,000/1000 $\mathrm{VND} /$ year.

\subsubsection{Indirect Use Value of Kimhy Reserve, Kimhy Commune}

To fertilize the terrace fields

The trees lost their leaves and dry branches annually that fertilize the organic for land after they were rotten so that the cost for rice and corn production in Kimhy commune are smaller than that of others. There was $60 \%$ households realized that they got benefit from Kimhy decreasing rice production cost, $32 \%$ in which perceived that the cost reduce $10 \%$, while that of the rest agreed with $30 \%$ cost reduction because of Kimhy. The cost reduction in rice production in Kimhy was 655/1000 VND per ha per year. We calculated the cost reduction for total rice area in Kimhy to estimate the value of Kimhy forest in fertilizing the terrace fields. There were 177.96 ha rice terrace fields that have $116,563 / 1000$ VND per year. 
Corn, was cultivated in Kimhy commune, also got benefit from Kimhy Reserve like rice production. There was $46.67 \%$ households perceived a change in the corn production cost reduction around $18.75 \%$ because the corn field more sloping than that of rice terrace fields or $412 / 1000 \mathrm{VND}$ per ha per year saving. Therefore, the annual value of Kimhy Reserve in Kimhy commune is 51,241/1000 VND.

\section{Mitigating the natural calamity, floods}

A lot of trees in Kimhy forest may be a good one to shield houses and fields of community from winds, storms, flood. In 2015, there were some serious storms in Nari and they destroyed houses and farms. However, to compare with other places, Kimhy community's damage was the lowest. Totally, the finance support after natural calamity, floods was 77 million VND, while that of other was 150 million VND. The gap was 73 million VND that was the value that Kimhy Reserve brought to Kimhy community.

\section{Carbon sequestration}

In Nari-Backan, there is 2000 ha Burretiodendron hsienmu (it is a species of flowering plant in the family Malvaceae). Its market price is very high in the world. The main area of Burretiodendron hsienmu concentrating in Kimhy has been taken care of community around as well as local leaders. Therefore, Calculating Carbon sequestration of Kimhy forest is very necessary for posing mechanism to protect Kimhy Reserve. There was only 3.33\% household knew the value of Carbon sequestration. Following the REED+ they will pay 75/1000 $\mathrm{VND} /$ ha/year for 0.2 Carbon sequestration increment. The total value equivalent of Carbon sequestration of Kimhy was 533,741/1000 VND with 7116.55 ha (Table 3).

\section{The value of Eco-tourism from Kimhy}

Kimhy Reserve in Kimhy commune that has 3 beautiful caves including Minhtinh cave, Khuoisao cave 1 and 2 so that there is an opportunity to develop eco-tourism in Kimhy. Homestays, 3 cave-sight-seeing, ethnic minority culture learning such as Dao, Tay should be perceived. From the record of local leaders, there were 3 teams came to Kimhy as tourists. They are also the people in Nari district but they were interested in beautiful places in Kimhy. By CVM, the willingness to pay of tourists to Kimhy was 50/1000 VND. But the small number of tourists (30) leaded to the small amount money of value of Kimhy, namely 1500/1000 VND.

\subsubsection{The Non-Use Value of Kimhy Reserve \\ Option value}

We use CVM to measure the willingness to pay to protect Kimhy Reserve because they perceived its benefit for their future usage. They wanted to keep Kimhy Reserve as deposit for future usage. There were 36 households agreed with paying money for protecting Kimhy from 2/1000 VND to 100/1000 VND. That information shows us how Kimhy Reserve is important for them including the direct use value, indirect use value. The total money we could get for option value was $25,152 / 1000$ VND by estimating willingness to pay (see Table 4). 
Table 3. The value of carbon sequestration of Kimhy forest, 60 household-respondents, Kimhy community, Na Ri, Backan, 2016.

\begin{tabular}{ccc}
\hline Content & Unit & Value \\
\hline $\begin{array}{c}\text { I. The knowledge of household about } \\
\text { Carbon sequestration of Kimhy forest } \\
\text { Yes }\end{array}$ & Household & 2 \\
No & Household & 58 \\
II. The value of & & \\
Carbon sequestration of Kimhy forest & & 1.0 \\
C annual increment & Ton C/ha/year & 0.2 \\
C increment paid by REED+ & Ton C/ha/year & 75,000 \\
Money equivalent paid by REED+ & $1000 \mathrm{VND} / \mathrm{ha} /$ year \\
Total money got from REED+ & $1000 \mathrm{VND} /$ year & 533,741 \\
\hline
\end{tabular}

Source: Survey results, 2016; 1US $=23,000 \$$ VND.

Table 4. Willingness to pay for option value, 60 household-respondents, Kimhy community, Na Ri, Backan, 2016.

\begin{tabular}{ccc}
\hline WTP (1000 VND) & Number of respondents & Percentage (\%) \\
\hline 2.00 & 1 & 2.8 \\
30.00 & 1 & 2.8 \\
40.00 & 1 & 2.8 \\
50.00 & 11 & 30.6 \\
100.00 & 13 & 36.1 \\
150.00 & 3 & 8.3 \\
200.00 & 5 & 13.8 \\
400.00 & 1 & 2.8 \\
\hline
\end{tabular}

Source: Survey results, 2016; 1US $=23,000 \$$ VND.

\section{The value of Use value and Non-use value for future generation}

We also use CVM to measure the willingness to pay to leave Kimhy for Use value and Non-use value for future generation. There were 26 households in total samples will pay for Kimhy protecting fund to keep Kimhy Reserve for future generation usage (43\%, see Table 5). From Table 5, the willingness to pay of household focused on 100/1000 VND - 200/1000 VND (average 161,000 VND/ household/year) because the they know about the value of Kimhy Reserve through the value of firewood, wild beast, aquatic product, honey, medicine plant, decorative plant, planting area, water usage, climate regulation, dust absorption, mitigating the natural calamity, floods, carbon sequestration, recreation, ... This information shows us the level of household in their role with future generation. The value of Use value and Non-use value for future generation is 27,907/1000 VND/year. 
Table 5. Willingness to pay for use value and non-use value for future generation, 60 household-respondents, Kimhy community, Na Ri, Backan, 2016.

\begin{tabular}{ccc}
\hline WTP (1000 VND) & Number of respondents & Percentage (\%) \\
\hline 50 & 3 & $11.5 \%$ \\
100 & 3 & $11.5 \%$ \\
120 & 1 & $3.8 \%$ \\
150 & 1 & $3.8 \%$ \\
200 & 16 & $61.5 \%$ \\
300 & 1 & $3.8 \%$ \\
400 & 1 & $3.8 \%$ \\
\hline
\end{tabular}

Source: Survey results, 2016; 1US $=23,000 \$$ VND.

\section{The exist value of Kimhy Reserve}

The natural resources in Kimhy Reserve are abundant. According to the Kimhy Reserve board's report, there are 798 species of plant, in which 65 species are very rare that has been recorded in the UCN Red List of Threatened Species. The fauna of Kimhy reservation is 386 species, in which 56 species are recorded in the UCN Red List of Threatened Species. Some kind of them only locates in the height of $600-900 \mathrm{~m}$ in Kimhy Reserve. That is the reason why Kimhy Reserve should be protected seriously so that government issue policies to support protecting natural resources in Kimhy (see Table 6).

There are 3 programs as Finance subsidization for community in Kimhy Reserve including 40 million VND/village program, Support to forestry guard team program, Support to use firewood saving-three leg stove program. The total money that community got from finance subsidization was 280 million VND/ year.

\subsubsection{Total Economic Value of Kimhy}

After we use the methods to measure the use and non-use value of Kimhy Reserve, the total economic value of Kimhy is 3,360,441/1000 VND/year. In which, the use value is $90.09 \%$, including the direct use value such as firewood, medicine plant, with 2,251,337/1000 VND/year, 66.96\% equivalent. The indirect use value is $776,045 / 1000 \mathrm{VND}$ /year. The non-use value of Kimhy Reserve is $333,059 / 1000 \mathrm{VND} /$ year (9.91\%) (Table 7).

\section{Conclusion}

Kimhy Reseve is the biggest reserve in the North of Vietnam. It protects diversity, keeps climate equable and maintains community's livelihood. Estimation of the economic value of Kimhy Reserve in Bac Kan plays an important role in protecting and managing Kimhy Reserve. The economic value of Kimhy Reserve includes the direct use value, indirect use value and non-use value includes existence value (EV) and bequest value (BV). To estimate the economic benefit generated from the Kimhy Reserve, the combination of market-based and CVM methods was used. 
Table 6. Finance subsidization for community in Kimhy reserve.

\begin{tabular}{ccc}
\hline Finance programs & Amount & Total value \\
\hline 40 million VND/village & 40 million VND/village & 280 million VND \\
Support to forestry guard team & 1.6 million VND/ha & No record because new policy \\
$\begin{array}{c}\text { Support to use firewood } \\
\text { saving-three leg stove }\end{array}$ & 2 million VND/household & No record because new policy \\
\hline
\end{tabular}

Source: Computed from primary data, 2016.

Table 7. Total economic value of Kimhy reserve, 2016.

\begin{tabular}{lcc}
\hline \multicolumn{1}{c}{ Total Economic value of Kimhy Reserve } & Value (1000 VND) & Rate (\%) \\
\hline I. Use value & $3,027,382$ & 90.09 \\
1) Direct use value & $2,251,337$ & 67.00 \\
a) Firewood & $1,264,000$ & 37.61 \\
b) The value of wild beast, aquatic product, honey & 56,000 & 1.67 \\
c) Medicine plant & 96,670 & 2.88 \\
d) Decorating plant & 22,000 & 0.65 \\
e) Value from breeding & 386,667 & 11.51 \\
f) Fruits and vegetables & 320,000 & 9.52 \\
g) Water use & 96,000 & 2.86 \\
f) Cultivation & 10,000 & 0.30 \\
2) Indirect use value & 776,045 & 23.09 \\
a) Rice field recovery & 116,563 & 3.47 \\
b) Corn field recovery & 51,241 & 1.52 \\
c) Mitigating the natural calamity, floods & 73,000 & 2.17 \\
d) Carbon sequestration & 533,741 & 15.88 \\
e) Eco-tourism & 1500 & 0.04 \\
II. Non-use value & 333,059 & 9.91 \\
1) Option value & 25,152 & 0.75 \\
2) The value of Use value and Non-use value & 27,907 & 0.83 \\
for future generation & 280,000 & 100.00 \\
3) The exist value of Kimhy Reserve & $3,360,441$ \\
\hline \multicolumn{1}{c}{ Total Economic value of Kimhy Reserve } & & \\
\hline & & \\
\hline
\end{tabular}

Source: Survey results, 2016; 1US $=23,000 \$$ VND.

For the local community, Kimhy Reserve brings more value in term of provision or direct use value $(2,251,337 / 1000 \mathrm{VND})$ such as firewood, medicine plant, value from breeding, fruits, vegetables, water use, cultivation. However, the indirect use value such as rice field and corn field protection, calamity mitigation, carbon sequestration and tourism is about (776,045/1000 VND) and non-use value is about $333,059 / 1000$ VND. Therefore, Kimhy Reserve is one main source that brings a lot of economic benefit to community $(3,360,441 / 1000$ 
VND/year). It is important to enhance the sense and conscious of economic value of Kimhy Reserve.

The Kimhy Reserve plays very important roles not only for local community, but also human being in term of climate regulation, genetic resource, disturbance and natural hazard regulation, education, recreation, aesthetic value, ... so that in future work, the study will focus more on those services to complement this study to better estimate when assessing the total benefits of forest reserve.

\section{Conflicts of Interest}

The authors declare no conflicts of interest regarding the publication of this paper.

\section{References}

Atkinson, G., \& Mourato, S. (2008). Environmental Cost-Benefit Analysis. Annual Review of Environment and Resources, 33, 317-344. https://www.annualreviews.org/doi/10.1146/annurev.environ.33.020107.112927

Nari People's Committee $(2013,2014,2015)$. Official Report on Kimhy Reserve.

Ninan, K. N., \& Inoue, M. (2013). Valuing Forest Ecosystem Services: Case Study of a Forest Reserve in Japan. Ecosystem Services, 5, 78-87. https://doi.org/10.1016/j.ecoser.2013.02.006

Riccardo, S., Susan, M. C., Hutchinson, W. G., \& Joseph, B. (1999). Valuing the Recreational Benefits from the Creation of Nature Reserves in Irish Forests. Working Papers, Fondazione Eni Enrico Mattei.

Rolfe, J., \& Windle, J. (2005). Valuing Options for Reserve Water in the Fitzroy Basin. Australian Journal of Agricultural and Resource Economics, Australian Agricultural and Resource Economics Society, 49, 1-24. https://doi.org/10.1111/j.1467-8489.2005.00265.x

Sharma, B., Rasul, G., \& Chettri, N. (2015). The Economic Value of Wetland Ecosystem Services: Evidence from the Koshi Tappu Wildlife Reserve, Nepal. Ecosystem Services, 12, 84-93. https://doi.org/10.1016/j.ecoser.2015.02.007

Song, N. V. (2008). Wildlife Trading in Vietnam: Causes, and Solutions. The Journal of Environment \& Development, 2, 145-165. https://doi.org/10.1177/1070496508316220

Truong, D. D. (2012). Estimation of the Economic Value of Wetland in Balat. Ph.D. Dissertation, Namdinh, Vietnam.

Xue, D., \& Tisdell, C. A. (2000). Valuing Ecological Functions of Biodiversity in Changbaishan Mountain Reserve in Northeast China. Economics, Ecology and Environment Working Papers, University of Queensland, School of Economics. 